\title{
Mechanochemical synthesis and effect of various additives on the hydrogen absorption-desorption behavior of $\mathrm{Na}_{3} \mathrm{AlH}_{6}$
}

\author{
Kateryna Peinecke ${ }^{1}$, Mariem Meggouh ${ }^{1}$, and Michael Felderhoff ${ }^{1, *}$ (1) \\ ${ }^{1}$ Max-Planck-Institut für Kohlenforschung, Kaiser-Wilhelm-Platz 1, 45470 Mülheim an der Ruhr, Germany
}

Received: 15 February 2018

Accepted: 28 March 2018

Published online:

9 April 2018

(C) The Author(s) 2018

\begin{abstract}
Sodium aluminum hydride has been extensively investigated for hydrogen storage applications whereas its intermediate decomposition compound $\mathrm{Na}_{3} \mathrm{AlH}_{6}$ received much less attention, despite having a lower dissociation pressure and a reasonable hydrogen storage capacity of $3.0 \mathrm{wt} \%$. In this work, $\mathrm{Na}_{3} \mathrm{AlH}_{6}$ is synthesized through ball milling, starting from $\mathrm{NaAlH}_{4}$ and $2 \mathrm{NaH}$ in the presence of $\mathrm{TiCl}_{3}$ catalyst precursor, and evaluated on its hydrogen sorption properties and cycle stability. Further addition of $8 \mathrm{~mol} \% \mathrm{Al}$ and $8 \mathrm{~mol} \%$ activated carbon (AC) and their effect on both the hydrogen sorption properties and cycle stability have been investigated. In order to explore whether the introduction of the $\mathrm{Al}$ and $\mathrm{AC}$ additives would be more beneficial (in terms of hydrogen sorption behavior and cycle stability) after the $\mathrm{Na}_{3} \mathrm{AlH}_{6}$ synthesis or during its synthesis, pre-synthesized $\mathrm{Na}_{3} \mathrm{AlH}_{6}$-based measurements were also included in this work. $\mathrm{TiCl}_{3}$-catalyzed $\mathrm{NaAlH}_{4}+2 \mathrm{NaH}$ sample showed a stable reversible hydrogen storage capacity of $1.7 \mathrm{wt} \%$, which was further increased to $2.1 \mathrm{wt} \%$ with the addition of Al-powder and activated carbon AC.
\end{abstract}

\section{Introduction}

Complex metal hydrides have gained much interest as hydrogen storage materials for practical applications due to their relative high theoretical gravimetric hydrogen capacity. Unfortunately, many complex metal hydrides require high pressures and temperatures for their hydrogenation and high temperature for dehydrogenation. Researchers have therefore focused on altering the thermodynamics for dehy- drogenation of these complex metal hydrides to lower the temperature of hydrogen release and improving the kinetics for the hydrogenation and dehydrogenation reactions [1,2]. Among the complex metal hydrides, sodium alanate, $\mathrm{NaAlH}_{4}$, has acquired much attention as a potential hydrogen storage material since it was reported to be reversible through doping with small amounts of Ti-catalysts [3]. $\mathrm{NaAlH}_{4}$ has a theoretical reversible hydrogen

Address correspondence to E-mail: felderhoff@mpi-muelheim.mpg.de 
storage capacity of $5.6 \mathrm{wt} \%$ and releases its hydrogen according to Eqs. (1) and (2).

$\mathrm{NaAlH}_{4} \rightleftharpoons 1 / 3 \mathrm{Na}_{3} \mathrm{AlH}_{6}+2 / 3 \mathrm{Al}+\mathrm{H}_{2}$

$1 / 3 \mathrm{Na}_{3} \mathrm{AlH}_{6} \rightleftharpoons \mathrm{NaH}+1 / 3 \mathrm{Al}+1 / 2 \mathrm{H}_{2}$

Despite its lower hydrogen capacity of $3.0 \mathrm{wt} \%$, $\mathrm{Na}_{3} \mathrm{AlH}_{6}$ has attracted also attention as a potential hydrogen storage material, because of much lower dissociation pressure than $\mathrm{NaAlH}_{4}$ (6 vs. 66 bar at $150{ }^{\circ} \mathrm{C}$, respectively) and therefore making it more suitable for practical applications [3]. Formed in the first decomposition step of $\mathrm{NaAlH}_{4}(1), \mathrm{Na}_{3} \mathrm{AlH}_{6}$ can also be directly synthesized through the reaction of $2 \mathrm{NaH}$ and $\mathrm{NaAlH}_{4}$ in heptane at $160{ }^{\circ} \mathrm{C}$ [4] or through hydrogenation of $\mathrm{Na}$ and $\mathrm{Al}$ in toluene at $165^{\circ} \mathrm{C}$ [5]. More recently, direct synthesis of $\beta-\mathrm{Na}_{3} \mathrm{AlH}_{6}$ was also achieved through mechanical milling of $\mathrm{NaAlH}_{4}$ and 2 $\mathrm{NaH}$ [6] and from $\mathrm{NaH}$ and $\mathrm{Al}$ in the presence of $4 \mathrm{~mol} \% \mathrm{TiF}_{3}$ under hydrogen pressure [7]. Furthermore, it was found that $\mathrm{Na}_{3} \mathrm{AlH}_{6}$ synthesized through mechanical milling exhibited faster kinetics than $\mathrm{Na}_{3} \mathrm{AlH}_{6}$ obtained from the decomposition of $\mathrm{NaAlH}_{4}$ [8]. $\mathrm{Na}_{3} \mathrm{AlH}_{6}$ proved to be reversible through the addition of Ti compounds [3]; however, doping with $\mathrm{Zr}$ compounds was reported to have better effect on the dehydrogenation of $\mathrm{Na}_{3} \mathrm{AlH}_{6}$ than doping with $\mathrm{Ti}[8,9]$. Although a large number of experimental results have been described on $\mathrm{NaAlH}_{4}$, a small number of studies have been reported on $\mathrm{Na}_{3} \mathrm{AlH}_{6}$ and its use as a hydrogen storage material. So far the studies on $\mathrm{Na}_{3} \mathrm{AlH}_{6}$ deal with theoretical calculations of structural parameters, effect of Ti doping, and hydrogen diffusion in pure and Ti-doped $\mathrm{Na}_{3} \mathrm{AlH}_{6}$. To our knowledge, no extensive study on the direct synthesis of $\mathrm{Na}_{3} \mathrm{AlH}_{6}$ through mechanochemical processes and the effect of various additives on the hydrogenation and dehydrogenation behavior has been reported so far. In this work, we investigate the synthesis of $\mathrm{Na}_{3} \mathrm{AlH}_{6}$ starting from $\mathrm{NaAlH}_{4}$ and $\mathrm{NaH}$ in the presence of $\mathrm{TiCl}_{3}$, combined with the addition of $\mathrm{Al}$ and $\mathrm{AC}$. It has been reported that addition of $\mathrm{AC}$ to Ti-doped $\mathrm{NaAlH}_{4}$ not only resulted in improved dehydrogenation and hydrogenation kinetics but also enhanced the cycle life [10] and ability to conduct heat [11]. We also investigate whether the additives are best added during or after the $\mathrm{Na}_{3} \mathrm{AlH}_{6}$ synthesis in order to obtain the optimum performance of the material. The long-term cycle stability measurements are performed at $170{ }^{\circ} \mathrm{C}$, which allows using this material in combination with HT-PEM fuel cells.

\section{Experimental}

The starting materials $\mathrm{NaH}(60 \%$ dispersion in mineral oil, Sigma-Aldrich Chemical) and $\mathrm{NaAlH}_{4}$ (technical grade, Sigma-Aldrich Chemical) were further purified to obtain $98 \%$ purity. $\mathrm{NaH}$ was cleaned from mineral oil by washing with pentane and $\mathrm{NaAlH}_{4}$ was purified by dissolving in THF solution, and then recrystallized using toluene. $\mathrm{TiCl}_{3}$ (ReagentPlus ${ }^{\circledR}$, Sigma-Aldrich Chemical), AC (activated carbon) $\left(0.79 \mathrm{~cm}^{3} \mathrm{~g}^{-1}\right.$, Carbo Tech), $\mathrm{Al}$ (99\%, Aluminum Rheinfelden), and doped $\mathrm{NaAlH}_{4}$ with $4 \mathrm{~mol} \% \mathrm{TiCl}_{3}$ (prepared in house) were used without further purification. The samples $(2.2 \mathrm{~g})$ were prepared by mechanical milling for $4 \mathrm{~h}$ under inert atmosphere (Ar) using hardened steel grinding bowls and grinding balls $(\varnothing=10 \mathrm{~mm})$ in a Fritsch Planetary Mono Mill Pulverisette 6 at $450 \mathrm{rpm}$, with a ball-topowder ratio of 30:1.

The samples characterized by X-ray diffraction were measured in transmission mode with a curved germanium (111) monochromator (STOE STADI P). Five samples: as-received $\mathrm{NaH}$, as-received $\mathrm{NaAlH}_{4}$, as-milled $\mathrm{NaAlH}_{4}+4 \mathrm{~mol} \% \quad \mathrm{TiCl}_{3}, \mathrm{NaAlH}_{4}+$ $4 \mathrm{~mol} \% \mathrm{TiCl}_{3}+2 \mathrm{NaH}$, and $\mathrm{NaAlH}_{4}+4 \mathrm{~mol} \%$ $\mathrm{TiCl}_{3}+2 \mathrm{NaH}+8 \mathrm{~mol} \% \mathrm{Al}+8 \mathrm{~mol} \% \quad \mathrm{AC}$ were characterized using an image plate detector, $\mathrm{Cu}-\mathrm{K} \alpha$ radiation $(1.541 \AA)$, and capillary ( $\varnothing=0.5 \mathrm{~mm})$. Three as-milled samples: $\mathrm{Na}_{3} \mathrm{AlH}_{6}, \mathrm{Na}_{3} \mathrm{AlH}_{6}+4 \mathrm{~mol} \%$ $\mathrm{TiCl}_{3}$, and $\mathrm{Na}_{3} \mathrm{AlH}_{6}+4 \mathrm{~mol} \% \mathrm{TiCl}_{3}+8 \mathrm{~mol} \% \mathrm{Al}+$ $8 \mathrm{~mol} \%$ AC were characterized using a Mythen $1 \mathrm{~K}$ detector, Mo-radiation (0.7093 $\AA$ ), and capillary $(\varnothing=0.5 \mathrm{~mm})$.

Differential scanning calorimetry (DSC) measurements were carried out with a Mettler-Toledo TGA/ DSC1 Star ${ }^{\mathrm{e}}$ System, under 1 bar of flowing argon $\left(50 \mathrm{ml} \mathrm{min}{ }^{-1}\right)$ with a heating rate of $10^{\circ} \mathrm{C} \mathrm{min}{ }^{-1}$ from room temperature to a maximum temperature of $450{ }^{\circ} \mathrm{C}$. Thermal gravimetric analysis (TGA) measurements were carried out with a NETZSCH STA 449 C Jupiter, under 1 bar of flowing argon $\left(50 \mathrm{ml} \mathrm{min}{ }^{-1}\right)$ with a heating rate of $10{ }^{\circ} \mathrm{C} \mathrm{min} \mathrm{m}^{-1}$ $\left(\mathrm{Na}_{3} \mathrm{AlH}_{6}\right.$-based samples) or $2{ }^{\circ} \mathrm{C} \min ^{-1}\left(\mathrm{NaAlH}_{4}\right.$ based samples) from room temperature to a maximum temperature of $450{ }^{\circ} \mathrm{C}$. Handling and storing of samples were performed in an inert atmosphere (Ar) glove box (MBraun Unistar) with $<1 \mathrm{ppm}_{2}$ and $<1$ ppm $\mathrm{H}_{2} \mathrm{O}$.

Absorption-desorption cycle measurements were performed on a PCT-Pro 2000 (SETARAM). The tests 
were carried out using $2 \mathrm{~g}$ of material which was placed in the sample holder using an argon-filled glove box. Several stainless steel spacers were used to center the sample inside the sample holder, thereby reducing the empty space of the sample holder and increasing the accuracy of the measurement. The pressure was monitored using an MKS pressure transducer with an accuracy of $1.0 \%$ of the reading value. The temperature of the sample was measured inside the sample holder well using a type $\mathrm{K}$ thermocouple with an accuracy of $\pm 1.1^{\circ} \mathrm{C}$. The mass of the samples was measured on SCALTEC SBA 42 balance with an accuracy of $\pm 0.003 \mathrm{~g}$. The cycling conditions were performed at $170{ }^{\circ} \mathrm{C}$, with $2-\mathrm{h}$ hydrogenation cycles at 25 bar hydrogen pressure and 2 -h dehydrogenation cycles at 0.1 bar hydrogen pressure.

\section{Results and discussion}

\section{Ball-milled samples}

Figure 1 shows the X-ray diffraction (XRD) patterns of the starting materials $\mathrm{NaH}$ (Fig. 1a) and $\mathrm{NaAlH}_{4}$ (Fig. 1b) together with as-milled $\mathrm{NaAlH}_{4}$ containing samples. It was observed that ball milling $(4 \mathrm{~h})$ of $\mathrm{NaAlH}_{4}$ in the presence of $4 \mathrm{~mol} \% \mathrm{TiCl}_{3}$ resulted in the partial decomposition of $\mathrm{NaAlH}_{4}$ as diffraction peaks of $\mathrm{Na}_{3} \mathrm{AlH}_{6}, \mathrm{NaCl}$, and $\mathrm{Al}$ were found (Fig. 1c).

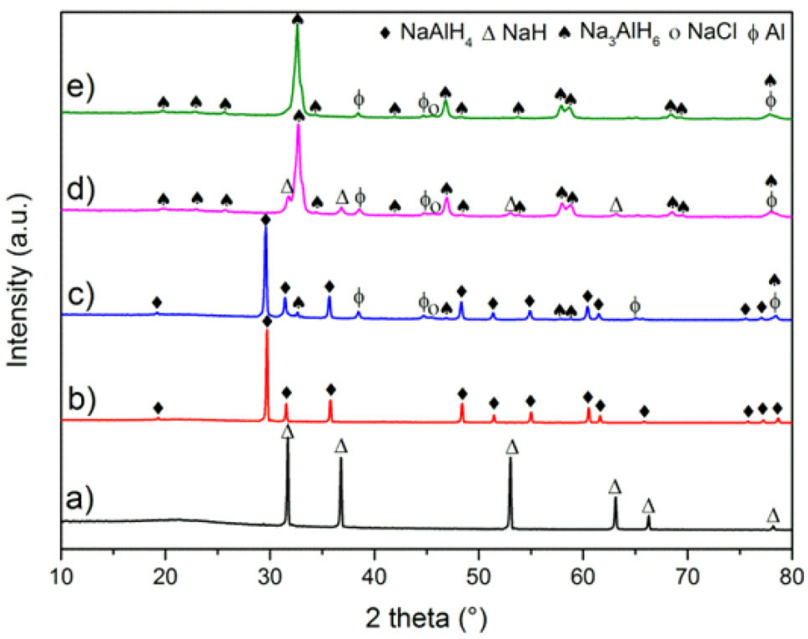

Figure 1 XRD diffraction patterns for: $a$ as-received $\mathrm{NaH}$, $b$ as-received $\mathrm{NaAlH}_{4}, c$ as-milled $\mathrm{NaAlH}_{4}+4 \mathrm{~mol} \% \mathrm{TiCl}_{3}$, $d$ as-milled $\mathrm{NaAlH}_{4}+2 \mathrm{NaH}+4 \mathrm{~mol} \% \mathrm{TiCl}_{3}$, and $e$ as-milled $\mathrm{NaAlH}_{4}+2 \mathrm{NaH}+4 \mathrm{~mol} \% \quad \mathrm{TiCl}_{3}+8 \mathrm{~mol} \% \quad \mathrm{Al}+8 \mathrm{~mol} \%$ $\mathrm{AC}(\mathrm{Cu}-\mathrm{K} \alpha$ radiation, $1.541 \AA)$.
Synthesis of $\mathrm{Na}_{3} \mathrm{AlH}_{6}$ was best achieved through ball milling of $2 \mathrm{~mol}$ of $\mathrm{NaH}$ and $\mathrm{NaAlH}_{4}$, in the presence of $8 \mathrm{~mol} \%$ of $\mathrm{Al}$ and $\mathrm{AC}$ (Fig. 1e) which showed (in contrary to Fig. 1d) no diffraction peaks of remaining $\mathrm{NaH}$. Although $\mathrm{TiCl}_{3}$ has been successfully applied as a dopant for sodium alanate systems, the catalytic mechanism remains unclear. It has been reported that during ball milling the titanium of $\mathrm{TiCl}_{3}$ is reduced to its metallic state [12]. However, addition of metallic titanium to $\mathrm{NaAlH}_{4}$ resulted in lower dehydrogenation capacities, indicating that the reduction in the dopant plays more complex role than presumed. The same applies for the Al-Ti compounds that have been proposed as the active species (rather than Ti), but when directly added, the similar results as for nondoped samples were obtained. Bogdanović et al. and Singh et al. reported that although the formation of $\mathrm{NaCl}$ as a by-product reduces the overall reversible hydrogen capacity, it acts as a grain refiner for $\mathrm{NaH}$. Similarly, $\mathrm{Al}_{x} \mathrm{Ti}_{y}$ species have been found to act as a grain refiner for $\mathrm{Al}$ as well, preventing particle growth [12-14]. The presence of grain refiners in combination with the vacancies and defects created during the ball-milling process seems to be crucial. It improves the mass transfer during hydrogenation and dehydrogenation, allowing faster kinetics. The absence of grain refiners would explain the poor results obtained for systems in which metallic Ti or Al-Ti was directly added [14].

In order to investigate the doping effect of the various additives, pre-synthesized $\mathrm{Na}_{3} \mathrm{AlH}_{6}$ was used (Fig. 2). XRD measurements showed that addition of $4 \mathrm{~mol} \% \mathrm{TiCl}_{3}$ alone did not result in a significant decomposition of $\mathrm{Na}_{3} \mathrm{AlH}_{6}$ (Fig. 2b), the weak $\mathrm{NaAlH}_{4}$ diffraction peak at $2 \theta$ values of $22^{\circ}$ was already present in the pre-synthesized $\mathrm{Na}_{3} \mathrm{AlH}_{6}$ (Fig. 2a). Furthermore, addition of $8 \mathrm{~mol} \%$ of both $\mathrm{Al}$ and $\mathrm{AC}$ showed no appearance of new phases (Fig. 2c). In fact, samples (b) and (c) are very similar.

Sandrock et al. [15] reported that although $\mathrm{TiCl}_{3}$ enhances the dehydriding and hydriding kinetics for both $\mathrm{NaAlH}_{4}$ and $\mathrm{Na}_{3} \mathrm{AlH}_{6}$, the effect is more pronounced for $\mathrm{NaAlH}_{4}$ than for $\mathrm{Na}_{3} \mathrm{AlH}_{6}$ (activation energy (desorption) for non-catalyzed $\mathrm{NaAlH}_{4}=$ $118 \mathrm{~kJ} \mathrm{~mol}^{-1}\left(\mathrm{H}_{2}\right)$, catalyzed $\left(4 \mathrm{~mol} \% \mathrm{TiCl}_{3}\right) \mathrm{NaAlH}_{4}$ $=80 \mathrm{~kJ} \mathrm{~mol}^{-1} \quad\left(\mathrm{H}_{2}\right)$, non-catalyzed $\mathrm{Na}_{3} \mathrm{AlH}_{6}=$ $121 \mathrm{~kJ} \mathrm{~mol}^{-1}\left(\mathrm{H}_{2}\right)$, catalyzed $\left(4 \mathrm{~mol} \% \quad \mathrm{TiCl}_{3}\right)$ $\left.\mathrm{Na}_{3} \mathrm{AlH}_{6}=98 \mathrm{~kJ} \mathrm{~mol}^{-1}\left(\mathrm{H}_{2}\right)\right)$. From the obtained XRD data, it seems that $\mathrm{Na}_{3} \mathrm{AlH}_{6}$ is less reactive toward the $\mathrm{TiCl}_{3}$ catalyst than $\mathrm{NaAlH}_{4}$, as no partial 


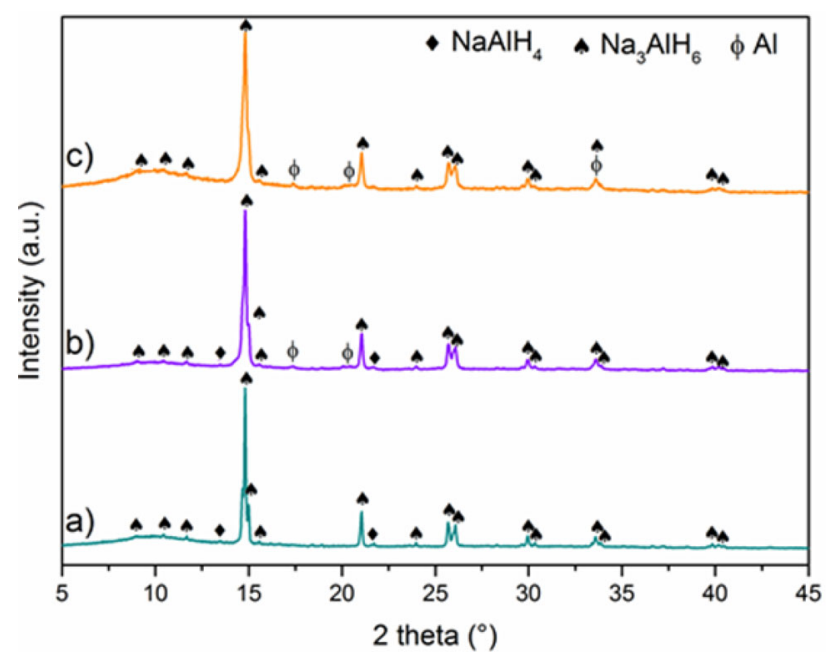

Figure 2 XRD diffraction patterns for $a$ as-prepared $\mathrm{Na}_{3} \mathrm{AlH}_{6}$, $b$ as-milled $\mathrm{Na}_{3} \mathrm{AlH}_{6}+4 \mathrm{~mol} \% \mathrm{TiCl}_{3}$, and $c$ as-milled $\mathrm{Na}_{3} \mathrm{AlH}_{6}$ $+4 \mathrm{~mol} \% \mathrm{TiCl}_{3}+8 \mathrm{~mol} \% \mathrm{Al}+8 \mathrm{~mol} \% \mathrm{AC}$ (Mo-radiation, $0.7093 \AA)$.

decomposition of $\mathrm{Na}_{3} \mathrm{AlH}_{6}$ was observed (i.e., formation of $\mathrm{NaCl}$ and $\mathrm{NaH}$ ). This was further emphasized by in situ pressure recording measurements during ball milling (Fig. 3) which showed that the pressure (from released hydrogen during the reduction of $\mathrm{TiCl}_{3}$ ) inside the milling vial increased to 5.2 bar for catalyzed $\mathrm{NaAlH}_{4}$, but only to 0.7 bar for catalyzed $\mathrm{Na}_{3} \mathrm{AlH}_{6}$. These results allowed for rough estimation of the molar quantity of $\mathrm{NaCl}$ produced assuming all $\mathrm{TiCl}_{3}$ has reacted, giving overall Eq. (3) and reversible

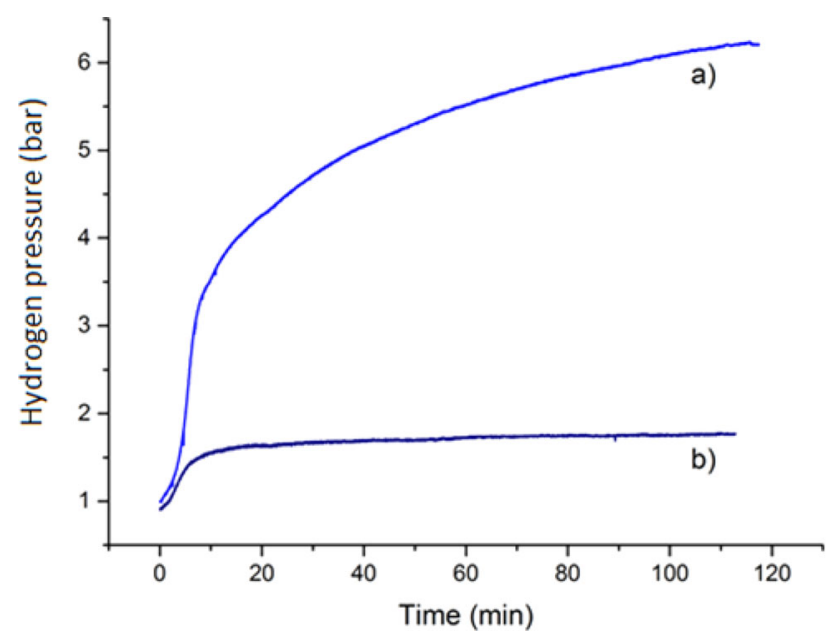

Figure 3 Pressure increase (from released hydrogen) during ballmilling process, $a \mathrm{NaAlH}_{4}+4 \mathrm{~mol} \% \mathrm{TiCl}_{3}, b$ milled $\mathrm{Na}_{3} \mathrm{AlH}_{6}$ $+4 \mathrm{~mol} \% \mathrm{TiCl}_{3}$. Note The hydrogen release zero value starts at 1 bar. hydrogen storage of $2.46 \mathrm{wt} \%$ for $\mathrm{NaAlH}_{4}$ $+2 \mathrm{NaH}+4 \mathrm{~mol} \% \mathrm{TiCl}_{3}$ as shown in Eq. (4). For the additive containing sample, the $\mathrm{Al}$ addition results in a slightly higher reversible hydrogen capacity (2.61 wt\%), see Eqs. (5) and (6).

$$
\begin{aligned}
& \mathrm{NaAlH}_{4}+2 \mathrm{NaH}+0.04 \mathrm{TiCl}_{3} \rightarrow 0.88 \mathrm{Na}_{3} \mathrm{AlH}_{6} \\
& +0.24 \mathrm{NaH}+0.12 \mathrm{NaCl}+0.04 \mathrm{TiAl}_{3}+0.24 \mathrm{H}_{2} \\
& 0.88 \mathrm{Na}_{3} \mathrm{AlH}_{6} \rightleftharpoons 2.64 \mathrm{NaH}+0.88 \mathrm{Al}+1.32 \mathrm{H}_{2} \\
& \mathrm{NaAlH}_{4}+2 \mathrm{NaH}+0.04 \mathrm{TiCl}_{3}+0.08 \mathrm{Al} \\
& \quad \rightarrow 0.96 \mathrm{Na}_{3} \mathrm{AlH}_{6}+0.12 \mathrm{NaCl}+0.04 \mathrm{TiAl}_{3} \\
& \quad+0.12 \mathrm{H}_{2} \\
& 0.96 \mathrm{Na}_{3} \mathrm{AlH}_{6} \rightleftarrows 2.88 \mathrm{NaH}+0.96 \mathrm{Al}+1.44 \mathrm{H}_{2} .
\end{aligned}
$$

\section{Thermal dehydrogenation}

Thermal decomposition behavior of the $\mathrm{NaAlH}_{4}{ }^{-}$ based samples was investigated using DSC measurements. Figure 4 shows the DSC curves of asreceived starting materials $\mathrm{NaH}$ (Fig. 4a) and $\mathrm{NaAlH}_{4}$ (Fig. 4b) together with milled samples when heated from room temperature to $450{ }^{\circ} \mathrm{C}$ under 1 bar of flowing argon at a heating rate of $10{ }^{\circ} \mathrm{C} \mathrm{min}^{-1}$. $\mathrm{NaAlH}_{4}$ in the presence of the $\mathrm{TiCl}_{3}$ catalyst precursor (Fig. 4c) showed small and weak endothermic events at 139 and $396{ }^{\circ} \mathrm{C}$, corresponding to the

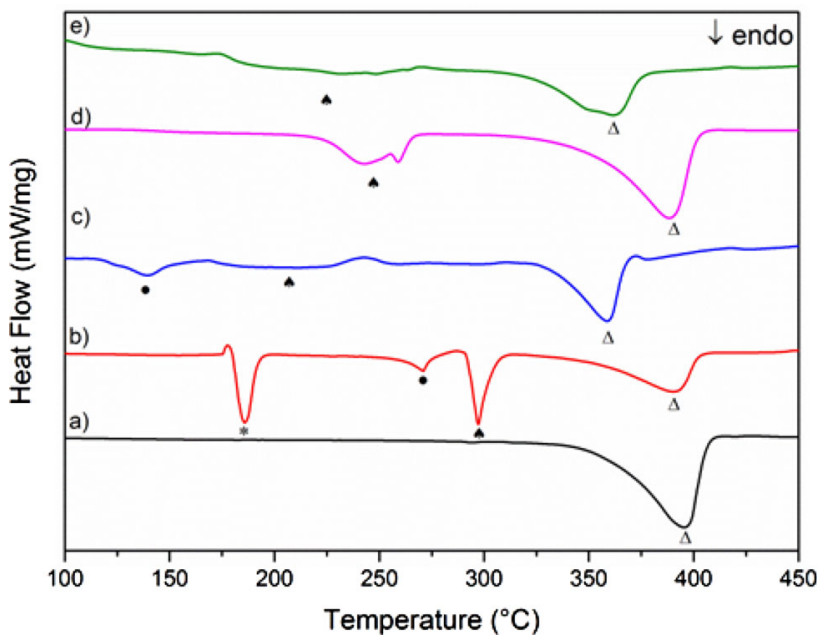

Figure 4 DSC curves for $a$ as-received $\mathrm{NaH}, b$ as-received $\mathrm{NaAlH}_{4}, c$ milled $\mathrm{NaAlH}_{4}+4 \mathrm{~mol} \% \mathrm{TiCl}_{3}$, $d$ milled $\mathrm{NaAlH}_{4}$ $+2 \mathrm{NaH}+4 \mathrm{~mol} \% \mathrm{TiCl}_{3}$, and $e$ milled $\mathrm{NaAlH}_{4}+2 \mathrm{NaH}+4$ $\mathrm{mol} \% \mathrm{TiCl}_{3}+8 \mathrm{~mol} \% \mathrm{Al}+8 \mathrm{~mol} \%$ AC. Samples were heated to $450{ }^{\circ} \mathrm{C}$ under 1 bar of flowing argon at $10{ }^{\circ} \mathrm{C} \mathrm{min}{ }^{-1}$. *, melting of $\mathrm{NaAlH}_{4}$; •, decomposition of $\mathrm{NaAlH}_{4}$; $\boldsymbol{\wedge}$, decomposition of $\mathrm{Na}_{3} \mathrm{AlH}_{6} ; \Delta$, decomposition of $\mathrm{NaH}$. 
decomposition of $\mathrm{NaAlH}_{4}$ and $\mathrm{NaH}$ which both occurred at much lower temperatures than their respective as-received materials, demonstrating the kinetic effect of the catalyst precursor. The weak and broad endothermic event between 169 and $227^{\circ} \mathrm{C}$ is contributed to the decomposition of $\mathrm{Na}_{3} \mathrm{AlH}_{6}$ (supported by TGA data, Fig. 7), whereas the cause for the exothermic event at $243{ }^{\circ} \mathrm{C}$ remains unclear. The most pronounced effect was observed for the sample containing ball-milled $\mathrm{NaAlH}_{4}$ in the presence of $2 \mathrm{~mol}$ of $\mathrm{NaH}$ and $4 \mathrm{~mol} \% \mathrm{TiCl}_{3}$ (Fig. $4 \mathrm{~d}$ ), which showed a double endothermic peak for the decomposition of $\mathrm{Na}_{3} \mathrm{AlH}_{6}$ between 225 and $250{ }^{\circ} \mathrm{C}$, followed by the endothermic peak for the decomposition of $\mathrm{NaH}$ around $390{ }^{\circ} \mathrm{C}$. No endothermic events corresponding to $\mathrm{NaAlH}_{4}$ were observed, further supporting the full conversion of $\mathrm{NaAlH}_{4}$ into $\mathrm{Na}_{3} \mathrm{AlH}_{6}$ during the ball-milling process as observed from XRD data (Fig. 1d). Further addition of $\mathrm{Al}$ and $\mathrm{AC}$ (Fig. 4e) resulted in a similar curve as obtained for the $\mathrm{TiCl}_{3}$-doped sample (Fig. 4c).

Figure 5 shows the DSC measurements for the $\mathrm{Na}_{3} \mathrm{AlH}_{6}$ containing milled samples which displayed no significant change for the thermal events, as found for the $\mathrm{NaAlH}_{4}$ containing samples, when heated from room temperature to $450{ }^{\circ} \mathrm{C}$ under 1 bar of flowing argon at a heating rate of $10{ }^{\circ} \mathrm{C} \mathrm{min}{ }^{-1}$. Asreceived $\mathrm{Na}_{3} \mathrm{AlH}_{6}$ showed two main endothermic events, the first is a complex event between 243 and

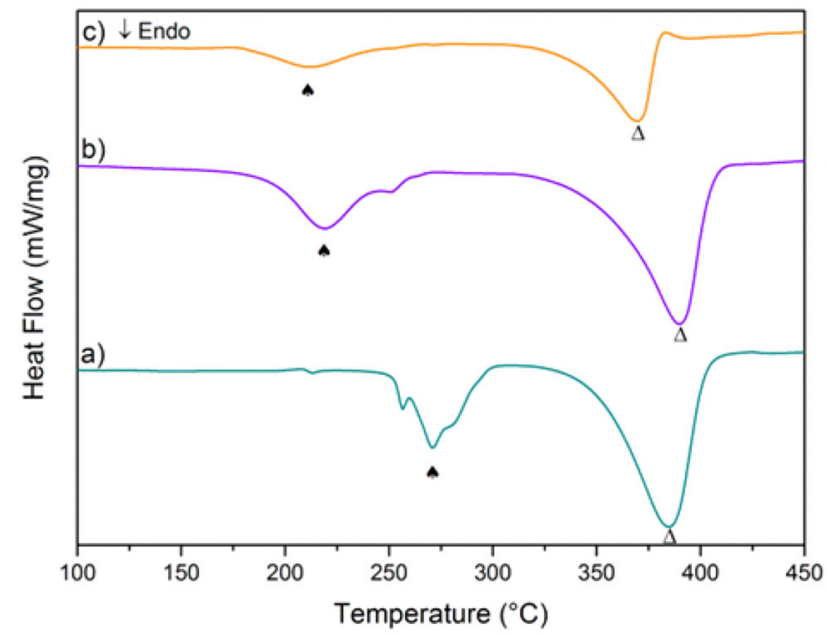

Figure 5 DSC curves for $a$ as-received $\mathrm{Na}_{3} \mathrm{AlH}_{6}, b \mathrm{Na}_{3} \mathrm{AlH}_{6}$ $+4 \mathrm{~mol} \% \mathrm{TiCl}_{3}$, and $c \mathrm{Na}_{3} \mathrm{AlH}_{6}+4 \mathrm{~mol} \% \mathrm{TiCl}_{3}+8 \mathrm{~mol} \%$ $\mathrm{Al}+8 \mathrm{~mol} \%$ AC. Samples were heated to $450{ }^{\circ} \mathrm{C}$ under 1 bar of flowing argon at $10{ }^{\circ} \mathrm{C} \mathrm{min}{ }^{-1} ; \boldsymbol{\Lambda}$, decomposition of $\mathrm{Na}_{3} \mathrm{AlH}_{6}$; and $\Delta$, decomposition of $\mathrm{NaH}$.
$304{ }^{\circ} \mathrm{C}$, corresponding to the decomposition of $\mathrm{Na}_{3} \mathrm{AlH}_{6}$ into elemental $\mathrm{Al}$ and $\mathrm{NaH}$. The second endothermic signal which occurred at $385{ }^{\circ} \mathrm{C}$ was caused by the decomposition of $\mathrm{NaH}$. For the $\mathrm{TiCl}_{3}$ catalyzed $\mathrm{Na}_{3} \mathrm{AlH}_{6}$ sample (Fig. 5b), the endothermic signal for the $\mathrm{Na}_{3} \mathrm{AlH}_{6}$ decomposition step was observed at much lower temperatures $\left(185-278{ }^{\circ} \mathrm{C}\right)$, whereas the endothermic peak for the decomposition of $\mathrm{NaH}$ took place at a higher temperature $\left(391^{\circ} \mathrm{C}\right)$. However, the lowest peak temperatures were obtained for the catalyzed $\mathrm{Na}_{3} \mathrm{AlH}_{6}$ sample with additional $8 \mathrm{~mol} \%$ of $\mathrm{Al}$ and $\mathrm{AC}$ (Fig. $5 \mathrm{c}$ ) with the $\mathrm{Na}_{3} \mathrm{AlH}_{6}$ decomposition reaction between 177 and $265{ }^{\circ} \mathrm{C}$ and the $\mathrm{NaH}$ decomposition peak at $370^{\circ} \mathrm{C}$.

$\mathrm{Na}_{3} \mathrm{AlH}_{6}$ is known to undergo phase transformation of $\alpha-\mathrm{Na}_{3} \mathrm{AlH}_{6}$ to $\beta-\mathrm{Na}_{3} \mathrm{AlH}_{6}$ around $252{ }^{\circ} \mathrm{C}$ $[15,16]$, and in order to detect this phase transformation rapid heating and fast data acquisition is needed [17]. Weidenthaler et al. [18] investigated the phase transformation using in situ DSC and hightemperature X-ray diffraction methods and found that using different heating rate resulted in different decomposition behavior. For example, they observed that the endothermic signals for the decomposition of $\mathrm{Na}_{3} \mathrm{AlH}_{6}$ and $\mathrm{NaH}$ shifted to higher temperatures with higher heating rates. A shoulder $\left(\sim 248^{\circ} \mathrm{C}\right)$ at the $\mathrm{Na}_{3} \mathrm{AlH}_{6}$ decomposition signal became apparent at heating rates $>10 \mathrm{~K} \mathrm{~min}^{-1}$, suggesting that another reaction is taken place prior to the decomposition of $\mathrm{Na}_{3} \mathrm{AlH}_{6}$ [18]. Figure 5a shows a shoulder

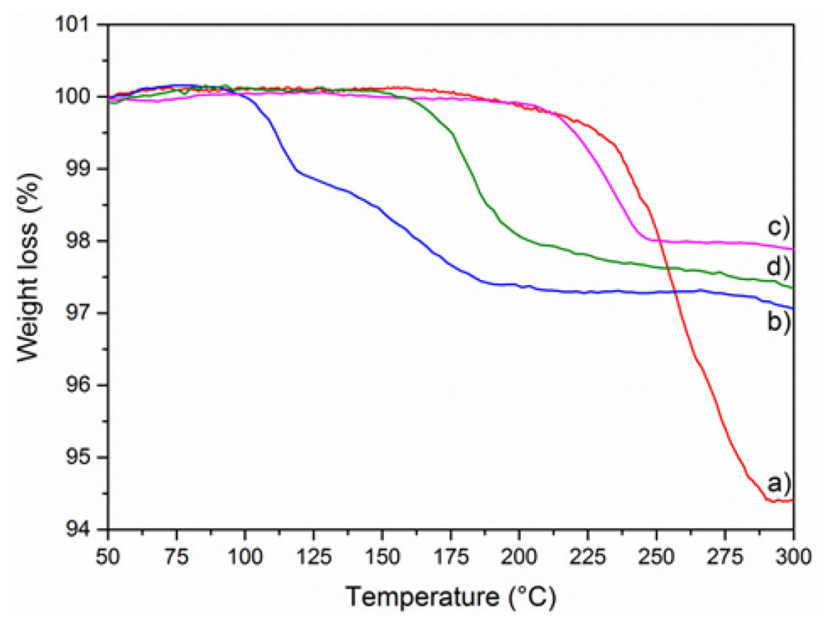

Figure 6 TGA curves for $a$ as-received $\mathrm{NaAlH}_{4}, b$ milled $\mathrm{NaAlH}_{4}+4$ mol\% $\mathrm{TiCl}_{3}, c$ milled $\mathrm{NaAlH}_{4}+2 \mathrm{NaH}+4 \mathrm{~mol} \%$ $\mathrm{TiCl}_{3}$, and $d$ milled $\mathrm{NaAlH}_{4}+2 \mathrm{NaH}+4 \mathrm{~mol} \% \quad \mathrm{TiCl}_{3}$ $+8 \mathrm{~mol} \% \mathrm{Al}+8 \mathrm{~mol} \% \mathrm{AC}$. Samples were heated to $300{ }^{\circ} \mathrm{C}$ under 1 bar of flowing argon at $2{ }^{\circ} \mathrm{C} \mathrm{min}^{-1}$. 
at $256{ }^{\circ} \mathrm{C}$ which is believed to be the phase transformation of $\alpha-\mathrm{Na}_{3} \mathrm{AlH}_{6}$ to $\beta-\mathrm{Na}_{3} \mathrm{AlH}_{6}$. However, in the doped samples (Fig. 5b, c) this shoulder is not observed and is most likely due to increased kinetics resulting in the decomposition of $\alpha-\mathrm{Na}_{3} \mathrm{AlH}_{6}$ to $\mathrm{NaH}$ and $\mathrm{Al}$ without detectable formation of $\beta-\mathrm{Na}_{3} \mathrm{AlH}_{6}$.

The dehydrogenation curves for the $\mathrm{NaAlH}_{4}$ - and $\mathrm{Na}_{3} \mathrm{AlH}_{6}$-based samples are shown in Figs. 6 and 7, respectively, with their corresponding hydrogen release capacities listed in Table 1. As-received $\mathrm{NaAlH}_{4}$ (Fig. 6a) showed an onset dehydrogenation temperature of $189^{\circ} \mathrm{C}$ and hydrogen release capacity of $5.5 \mathrm{wt} \%$, which is close to its theoretical capacity of $5.6 \mathrm{wt} \%$. However, addition of $4 \mathrm{~mol} \%$ of $\mathrm{TiCl}_{3}$

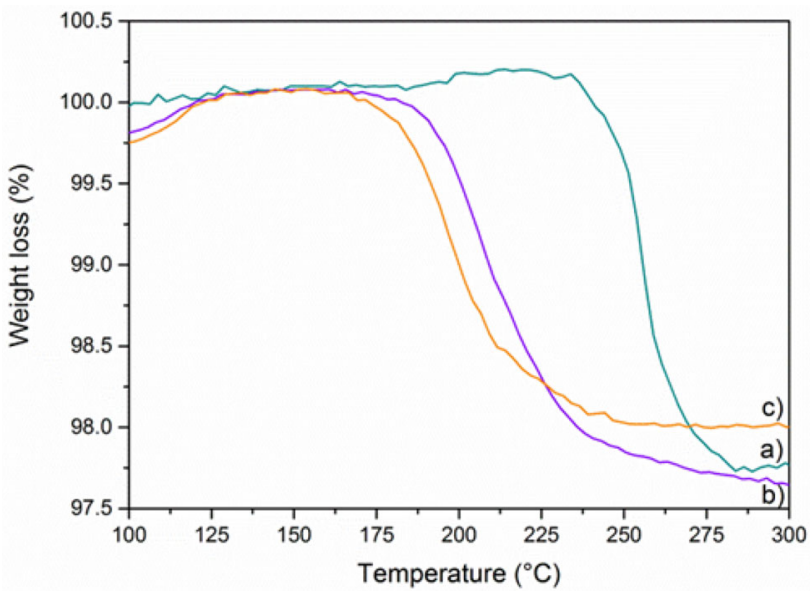

Figure 7 TGA curves for $a$ as-received $\mathrm{Na}_{3} \mathrm{AlH}_{6}, b \mathrm{Na}_{3} \mathrm{AlH}_{6}$ $+4 \mathrm{~mol} \% \mathrm{TiCl}_{3}$, and $c \mathrm{Na}_{3} \mathrm{AlH}_{6}+4 \mathrm{~mol} \% \mathrm{TiCl}_{3}+8 \mathrm{~mol} \%$ $\mathrm{Al}+8 \mathrm{~mol} \%$ AC. Samples were heated to $300{ }^{\circ} \mathrm{C}$ under 1 bar of flowing argon at $10{ }^{\circ} \mathrm{C} \mathrm{min}^{-1}$.
(Fig. 6b) resulted in an onset dehydrogenation temperature of $90^{\circ} \mathrm{C}$, a shift of roughly $100{ }^{\circ} \mathrm{C}$ compared to the pristine material, releasing hydrogen capacity of $4.2 \mathrm{wt} \%$. For $\mathrm{Na}_{3} \mathrm{AlH}_{6}$, the effect of $\mathrm{TiCl}_{3}$ was less pronounced (Fig. $7 \mathrm{~b}$ ) and resulted in a shift of roughly $50{ }^{\circ} \mathrm{C}$ to lower temperatures and hydrogen release capacity of $2.3 \mathrm{wt} \%$ compared to $2.4 \mathrm{wt} \%$ for the pristine $\mathrm{Na}_{3} \mathrm{AlH}_{6}$ (Table 1). From XRD data (Fig. 2b), this small effect was expected as no change was observed compared to pristine $\mathrm{Na}_{3} \mathrm{AlH}_{6}$.

For the sample containing both $4 \mathrm{~mol} \% \mathrm{TiCl}_{3}$ and $2 \mathrm{~mol} \mathrm{NaH} \mathrm{(Fig.} \mathrm{6c),} \mathrm{the} \mathrm{onset} \mathrm{dehydrogenation}$ temperature shifted to higher temperatures in comparison with the sample containing $4 \mathrm{~mol} \% \mathrm{TiCl}_{3}$ (Fig. 6b) and the sample containing $4 \mathrm{~mol} \% \mathrm{TiCl}_{3}$, $2 \mathrm{~mol} \mathrm{NaH}, 8 \mathrm{~mol} \% \mathrm{Al}$, and $8 \mathrm{~mol} \% \mathrm{AC}$ (Fig. 6d) and occurred at $206{ }^{\circ} \mathrm{C}$, providing a hydrogen release capacity of $2.0 \mathrm{wt} \%$ (Table 1). From XRD data (Fig. 1d), it could be observed that $\mathrm{Na}_{3} \mathrm{AlH}_{6}$ which was synthesized in situ through the addition of $\mathrm{NaH}$ resulted in a lower onset dehydrogenation temperature than found for as-received $\mathrm{Na}_{3} \mathrm{AlH}_{6}\left(233^{\circ} \mathrm{C}\right)$, Fig. 7a. In Fig. 6d, it can be seen that the hydrogen release capacity increased to $2.5 \mathrm{wt} \%$ (Table 1 ) when $8 \mathrm{~mol} \%$ of $\mathrm{Al}$ and $\mathrm{AC}$ were added to the $\mathrm{NaAlH}_{4}$ $+2 \mathrm{NaH}+4 \mathrm{~mol} \% \mathrm{TiCl}_{3}$ sample and gave an onset dehydrogenation temperature of $149^{\circ} \mathrm{C}$. Similar results were obtained for the doped $\mathrm{Na}_{3} \mathrm{AlH}_{6}$ sample when $8 \mathrm{~mol} \%$ of both $\mathrm{Al}$ and $\mathrm{AC}$ were added, showing an onset dehydrogenation temperature of $171{ }^{\circ} \mathrm{C}$ and a hydrogen release capacity of $2.6 \mathrm{wt} \%$. It seems that, for both the $\mathrm{NaAlH}_{4}$ - and $\mathrm{Na}_{3} \mathrm{AlH}_{6}$-based samples, the $\mathrm{Al}$ and $\mathrm{AC}$ additives reduced the onset

Table 1 Theoretical and experimental hydrogen capacities for the $\mathrm{NaAlH}_{4}$ - and $\mathrm{Na}_{3} \mathrm{AlH}_{6}$-based samples

\begin{tabular}{|c|c|c|c|}
\hline Sample & $\begin{array}{l}\text { Theoretical hydrogen } \\
\text { capacity (wt } \%)\end{array}$ & $\begin{array}{l}\text { Hydrogen capacity according } \\
\text { to Eqs. (4) and (6) (wt } \%)\end{array}$ & $\begin{array}{l}\text { Experimental hydrogen } \\
\text { capacity (wt } \%)\end{array}$ \\
\hline $\mathrm{NaAlH}_{4}$ as-received & 5.6 & 5.6 & 5.5 \\
\hline $\mathrm{NaAlH}_{4}+4 \mathrm{~mol} \% \mathrm{TiCl}_{3}$ & 5.2 & 4.4 & 4.2 \\
\hline $\mathrm{NaAlH}_{4}+2 \mathrm{NaH}+4 \mathrm{~mol} \% \mathrm{TiCl}_{3}$ & 2.9 & 2.5 & 2.0 \\
\hline $\begin{array}{l}\mathrm{NaAlH}_{4}+2 \mathrm{NaH}+4 \mathrm{~mol} \% \mathrm{TiCl}_{3}+8 \\
\mathrm{~mol} \% \mathrm{Al}+8 \mathrm{~mol} \% \mathrm{AC}\end{array}$ & 2.8 & 2.6 & 2.5 \\
\hline $\mathrm{Na}_{3} \mathrm{AlH}_{6}$ as-received & 3.0 & 3.0 & 2.4 \\
\hline $\mathrm{Na}_{3} \mathrm{AlH}_{6}+4 \mathrm{~mol} \% \mathrm{TiCl}_{3}$ & 2.9 & 2.5 & 2.3 \\
\hline $\begin{array}{l}\mathrm{Na}_{3} \mathrm{AlH}_{6}+4 \mathrm{~mol} \% \mathrm{TiCl}_{3}+8 \mathrm{~mol} \% \\
\mathrm{Al}+8 \mathrm{~mol} \% \mathrm{AC}\end{array}$ & 2.8 & 2.6 & 2.6 \\
\hline
\end{tabular}




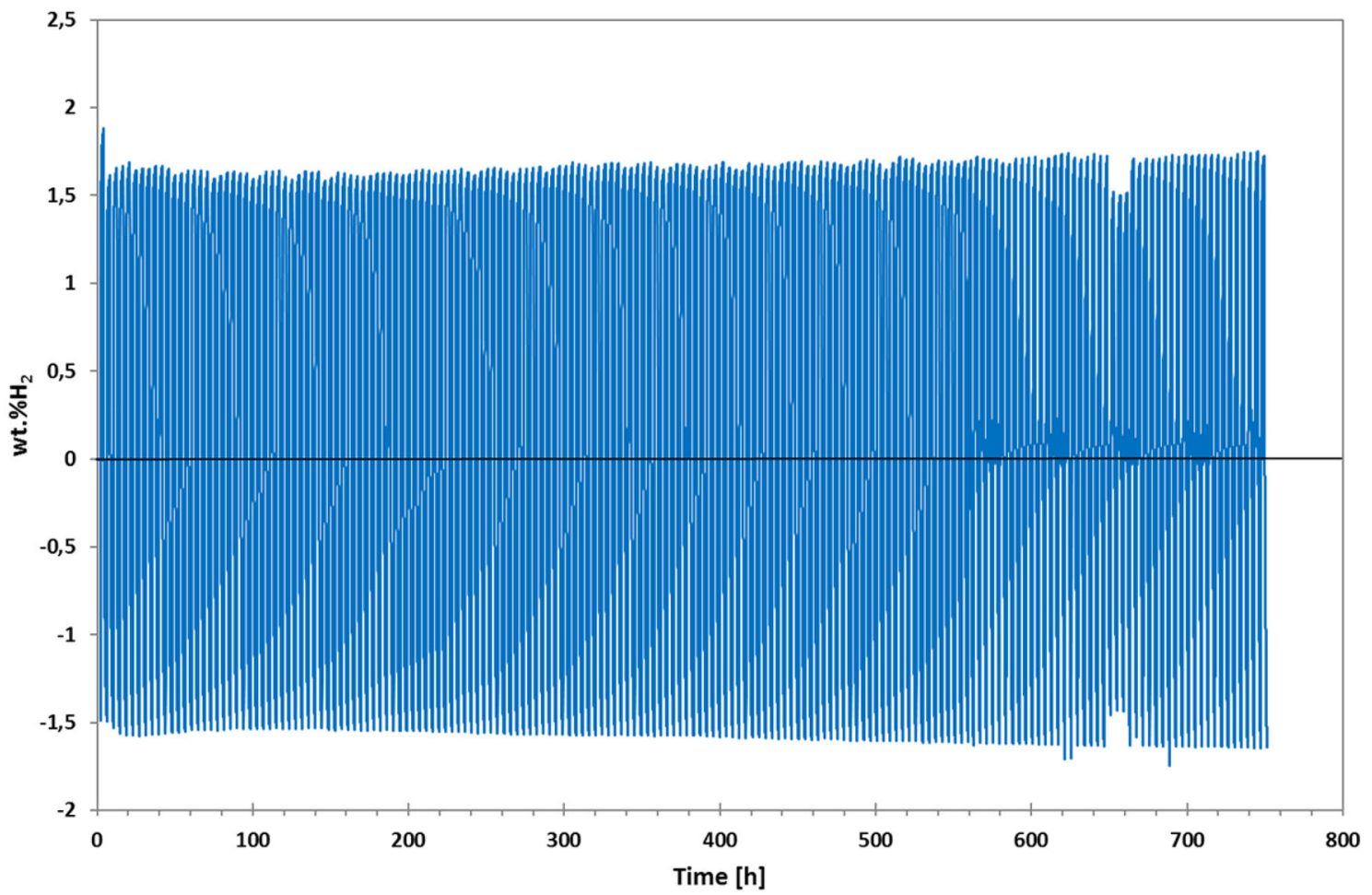

Figure 8 Long-term cycle stability test of milled $\mathrm{Na}_{3} \mathrm{AlH}_{6}+4 \mathrm{~mol} \% \mathrm{TiCl}_{3}$ after $750 \mathrm{~h}$ of operation with $2 \mathrm{~h}$ cycles of hydrogenation (28 bar $\mathrm{H}_{2}$ ) and dehydrogenation $\left(0.1\right.$ bar $\left.\mathrm{H}_{2}\right)$ at $170{ }^{\circ} \mathrm{C}$.

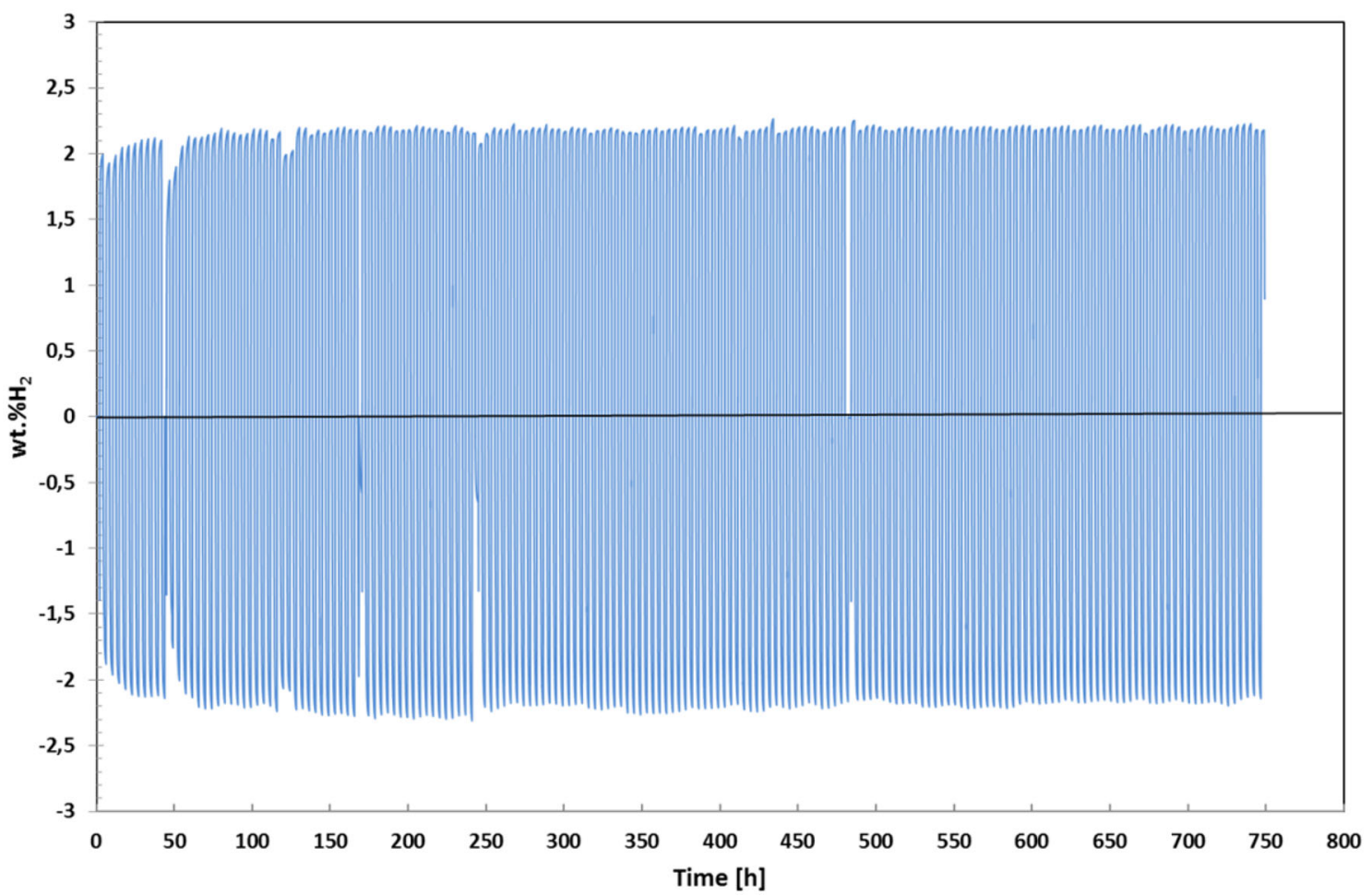

Figure 9 Long-term cycle stability test of milled $\mathrm{Na}_{3} \mathrm{AlH}_{6}+4 \mathrm{~mol} \% \mathrm{TiCl}_{3}+8 \mathrm{~mol} \% \mathrm{Al}+8 \mathrm{~mol} \% \mathrm{AC}$ after $750 \mathrm{~h}$ of operation with 2-h cycles of hydrogenation $\left(28\right.$ bar $\left.\mathrm{H}_{2}\right)$ and dehydrogenation $\left(0.1\right.$ bar $\left.\mathrm{H}_{2}\right)$ at $170{ }^{\circ} \mathrm{C}$. 
dehydrogenation temperatures further, possibly by increasing the dehydrogenation kinetics and the increased hydrogen release capacity through addition of $\mathrm{Al}$ as proposed in Eqs. (5) and (6).

\section{Cycle stability measurements}

Figure 8 shows the cycle stability measurement for the $\mathrm{Na}_{3} \mathrm{AlH}_{6}+4 \mathrm{~mol} \% \mathrm{TiCl}_{3}$ sample when subjected to 2-h hydrogenation $\left(28\right.$ bar $\mathrm{H}_{2}$ )/dehydrogenation $\left(0.1\right.$ bar $\mathrm{H}_{2}$ ) cycles at $170{ }^{\circ} \mathrm{C}$. The sample showed good cycle stability with a hydrogen capacity of $1.6 \mathrm{wt} \%$ at the start of the measurement which increased slightly to $1.7 \mathrm{wt} \%$ after $750 \mathrm{~h}$ [19]. No capacity loss was observed till $650 \mathrm{~h}$ of operation. However, at $650 \mathrm{~h}$ the capacity loss of $\sim 10-15 \%$ which lasted only for a few cycles (Fig. 8) was observed. This capacity loss was not observed for the $\mathrm{Na}_{3} \mathrm{AlH}_{6}+4 \mathrm{~mol} \% \quad \mathrm{TiCl}_{3}+8 \mathrm{~mol} \% \mathrm{Al}+8 \mathrm{~mol} \%$ $\mathrm{AC}$ sample and it's unclear as to the reason for its occurrence.

Addition of $8 \mathrm{~mol} \% \mathrm{Al}$ and $8 \mathrm{~mol} \% \mathrm{AC}$ to the $\mathrm{Na}_{3} \mathrm{AlH}_{6}$ with $4 \mathrm{~mol} \% \mathrm{TiCl}_{3}$ (same cycling conditions as for the $\mathrm{Na}_{3} \mathrm{AlH}_{6}+4 \mathrm{~mol} \% \mathrm{TiCl}_{3}$ sample) resulted in an increased hydrogen capacity of $2.2 \mathrm{wt} \%$ (Fig. 9) in comparison with $1.7 \mathrm{wt} \%$ (Fig. 8). The sample showed good cycle stability and in contrary to the $\mathrm{Na}_{3} \mathrm{AlH}_{6}+4 \mathrm{~mol} \% \mathrm{TiCl}_{3}$ sample, no capacity losses were observed during $750 \mathrm{~h}$ of operating. Electricity shutdown caused some interruption at around 50, 170, 250, and $480 \mathrm{~h}$ since beginning of the experiment.

\section{Conclusions}

Ball-milled sample containing $\mathrm{NaAlH}_{4}+2 \mathrm{NaH}+$ $4 \mathrm{~mol} \% \mathrm{TiCl}_{3}+8 \mathrm{~mol} \% \mathrm{Al}+8 \mathrm{~mol} \%$ AC gave better results compared to the sample containing $\mathrm{NaAlH}_{4}+2 \mathrm{NaH}+4 \mathrm{~mol} \% \mathrm{TiCl}_{3}$, with hydrogen capacities of 2.2 and $1.7 \mathrm{wt} \%$, respectively. The addition of $\mathrm{Al}$ allowed for the remaining $\mathrm{NaH}$ to react further into $\mathrm{Na}_{3} \mathrm{AlH}_{6}$ during the hydrogenation process, thereby increasing the hydrogen capacity. Cycle life stability measurements for both samples showed no sign of performance loss up to $750 \mathrm{~h}$ of operation, allowing the use as hydrogen storage materials in combination with HT-PEM fuel cell applications.

\section{Acknowledgements}

Open access funding provided by Max Planck Society. Financial support by Ministerium für Wirtschaft, Energie, Bauen, Wohnen und Verkehr des Landes Nordrhein-Westfalen and European Regional Development Fund (ERDF) (Funding No. ef003a) is much appreciated. The authors gratefully acknowledge the Max Planck Society for basic funding. The authors thank Dr. Claudia Weidenthaler and Jan Ternieden for measurement and interpretation of X-ray diffraction patterns.

Open Access This article is distributed under the terms of the Creative Commons Attribution 4.0 International License (http://creativecommons.org/ licenses/by/4.0/), which permits unrestricted use, distribution, and reproduction in any medium, provided you give appropriate credit to the original author(s) and the source, provide a link to the Creative Commons license, and indicate if changes were made.

\section{References}

[1] Jain IP, Jain P, Jain A (2010) Novel hydrogen storage materials: a review of lightweight complex hydrides. J Alloys Compd 503:303-339

[2] Sakintuna B, Lamari-Darkrim F, Hirscher M (2007) Metal hydride materials for solid hydrogen storage: a review. Int $\mathrm{J}$ Hydrogen Energy 32:1121-1140

[3] Bogdanović B, Schwickardi M (1997) Ti-doped alkali metal aluminium hydrides as potential novel reversible hydrogen storage materials. J Alloys Compd 253-254:1-9

[4] Zakharkin LI, Gavrilenko VV (1962) The direct synthesis of sodium and potassium aluminum hydrides from the elements. Dokl Akad Nauk SSSR 145:793-796

[5] Ashby EC, Kobetz P (1966) The direct synthesis of $\mathrm{Na}_{3} \mathrm{AlH}_{6}$. Inorg Chem 5:1615-1617

[6] Huot J, Boily S, Guther V, Schulz R (1999) Synthesis of $\mathrm{Na}_{3} \mathrm{AlH}_{6}$ and $\mathrm{Na}_{2} \mathrm{LiAlH}_{6}$ by mechanical alloying. $\mathrm{J}$ Alloys Compd 283:304-306

[7] Wang P, Kang XD, Cheng HM (2005) Direct formation of $\mathrm{Na}_{3} \mathrm{AlH}_{6}$ by mechanical milling $\mathrm{NaH} / \mathrm{Al}$ with $\mathrm{TiF}_{3}$. Appl Phys Lett 87:071911

[8] Kircher O, Fichtner M (2005) Kinetic studies of the decomposition of $\mathrm{NaAlH}_{4}$ doped with a Ti-based catalyst. J Alloys Compd 404-406:339-342

[9] Zidan RA, Takara S, Hee AG, Jensen CM (1999) Hydrogen cycling behavior of zirconium and titanium-zirconium- 
doped sodium aluminum hydride. J Alloys Compd 285:119-122

[10] Mao J, Guo Z, Liu H (2012) Enhanced hydrogen storage properties of $\mathrm{NaAlH}_{4}$ co-catalysed with niobium fluoride and single-walled carbon nanotubes. RSC Adv 2:1569-1576

[11] Adelhelm P, de Jongh PE (2011) The impact of carbon materials on the hydrogen storage properties of light metal hydrides. J Mater Chem 21:2417-2427

[12] Léon A, Schild D, Fichtner M (2005) Chemical state of Ti in sodium alanate doped with $\mathrm{TiCl}_{3}$ using X-ray photoelectron spectroscopy. J Alloys Compd 404-406:766-770

[13] Bogdanović B, Eberle U, Felderhoff M, Schüth F (2007) Complex aluminium hydrides. Scr Mater 56:813-816

[14] Singh S, Eijt SWH, Huot J, Kockelmann WA, Wagemaker M, Mulder FM (2007) The $\mathrm{TiCl}_{3}$ catalyst in $\mathrm{NaAlH}_{4}$ for hydrogen storage induces grain refinement and impacts on hydrogen vacancy formation. Acta Mater 55:5549-5557

[15] Sandrock G, Gross K, Thomas G (2002) Effect of Ti-catalyst content on the reversible hydrogen storage properties of the sodium alanates. J Alloys Compd 339:299-308
[16] Bastide J-P, Bonnetot B, Létoffé J-M, Claudy P (1981) Polymorphisme de l'hexahydroaluminate trisodique $\mathrm{Na}_{3} \mathrm{AlH}_{6}$. Mater Res Bull 16:91-96

[17] Bogdanović B, Brand RA, Marjanović A, Schwickardi M, Tölle J (2000) Metal-doped sodium aluminium hydrides as potential new hydrogen storage materials. J Alloys Compd 302:36-58

[18] Weidenthaler C, Pommerin A, Felderhoff M, Schmidt W, Bogdanović B, Schüth F (2005) Evidence for the existence of $\beta-\mathrm{Na}_{3} \mathrm{AlH}_{6}$ : monitoring the phase transformation from $\alpha$ $\mathrm{Na}_{3} \mathrm{AlH}_{6}$ by in situ methods. J Alloys Compd 398:228-234

[19] Urbancyk R, Peinecke K, Felderhoff M, Hauschild K, Kersten W, Peil S, Bathen D (2014) Aluminium alloy based hydrogen storage tank operated with sodium aluminium hexahydride $\mathrm{Na}_{3} \mathrm{AlH}_{6}$. Int $\mathrm{J}$ Hydrogen Energy 39:17118-17128 